\title{
GUIDELINES
}

\section{ANTIRETROVIRAL THERAPY IN CHILDREN}

\section{Southern African HIV Clinicians Society}

The Paediatric Sub-committee of the Southern African HIV Clinicians Society comprises paediatricians from the private and public sectors. These guidelines are the result of reviewing all the available paediatric treatment guidelines, consulting with international experts and drawing from their clinical experience. They differ from those of the National Department of Health (DOH), the World Health Organization (WHO) and other international guidelines (PENTA, etc). We encourage all treaters to consult the other guidelines, and make an informed decision for treating children. Websites of other guidelines can be found below under 'Recommended reading.' For the benefit of those working in the State Sector, a summary of the DOH Guidelines can be found in this journal on page 33 .

The use of antiretroviral therapy (ART) in children is a highly specialised field. Initial and ongoing management of the HIVinfected child by a practitioner experienced in this field is strongly recommended. If this is not possible, we recommend consultation with an informed paediatrician before initiation of ART, so that the child may benefit from the most optimal regimen. Certainly, decisions regarding change of regimen or the use of specific drugs and decisions related to stopping treatment are best made in consultation with experienced clinicians.

ART in children follows the same general principles as in adults. The main differences are that dosing is more complex and is often based on surface area, liquid formulations requiring exact measurements are often necessary, and there are no fixed dose combinations for children yet. As children are growing, frequent re-adjustment of dosing is necessary.

\section{VIRAL DYNAMICS: PERSPECTIVES IN CHILDREN}

Viral loads in children are far higher in the first year of life than those in adults and only decline to adult values by 5 - 6
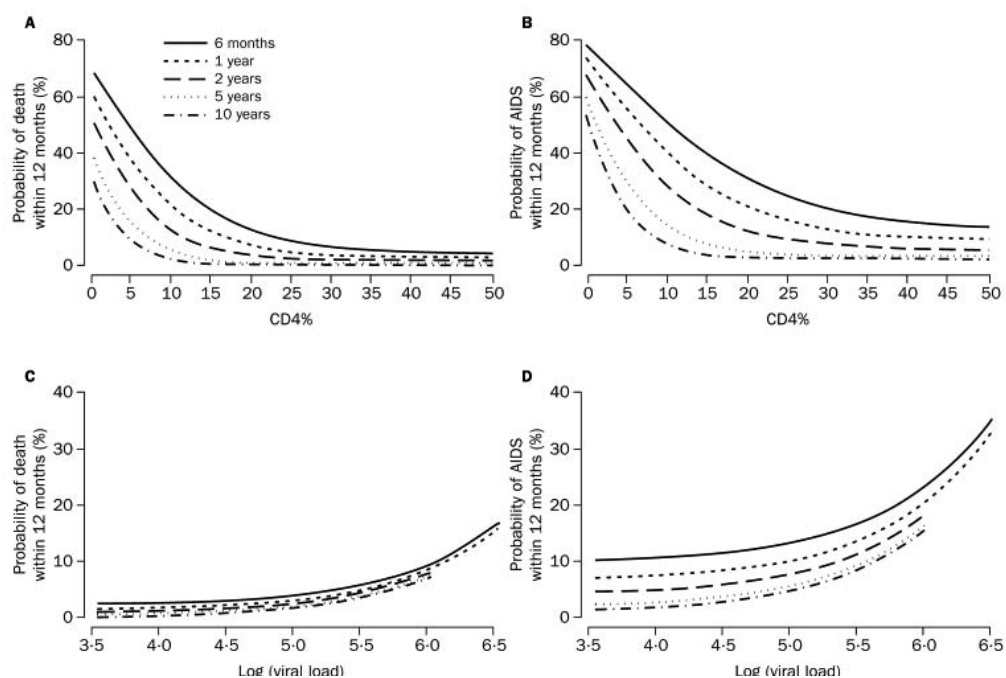

Fig. 1. CD4\% v. probability of death (A) and AIDS (B) in 12 months, and viral load v. probability of death (C) and AIDS (D) in 12 months (source - Lancet 2003; 362 1605-1611). years of age. By 2 months of age, most HIV-infected infants have viral loads above 100000 RNA copies/ml of plasma, ranging from undetectable to 10 million RNA copies $/ \mathrm{ml}$. The mean viral load in the first year of life is 185000 copies $/ \mathrm{ml}$. Generally, the higher the viral load, the more rapid the disease progression, although there is considerable variability.

Viral load assays are of value in assessing the efficacy of the regimen. A combination of viral load assay and CD4+ percentage is most predictive of mortality, although there is a stronger correlation with mortality for CD4 than viral load (Fig. 1). The prognostic value of $\mathrm{CD} 4+$ percentage is agedependent, with a higher value having a worse prognosis at a younger age than relatively low values at an older age.

\section{GOALS OF THERAPY}

The goals of therapy are:

Maximal and durable suppression of viral load

- Restoration or preservation of immunological function (usually measured with CD4+ count)

- Improvement in clinical symptoms

Reduction in morbidity and mortality.

The overall objective of therapy is to enhance the quality and quantity of life and to promote physical, social and intellectual development of the child within a functional family setting. A practical goal is to avoid hospitalisation by minimising the impact of intercurrent disease, thus keeping the child with his/her family. Finally, the well-being of a child impacts positively on the parents, and a healthy parent is vital. In addition to antiretrovirals (ARVs), the following strategies are essential to the child:

- Prevention of opportunistic infections

- Aggressive treatment of intercurrent infections 


\section{COMBINATION THERAPY}

There is no role for mono- or dual therapy.

A combination of at least three drugs is mandatory. The higher viral loads in children may make suppression of plasma HIV RNA to below the limits of detection more difficult to achieve than in adults. However, with the potent combinations available today, plasma HIV RNA suppression should be achievable in the vast majority of patients.

While triple therapy is the most common regimen, quadruple therapy in children under 1 year of age and with high viral loads may have a role, especially when unboosted protease inhibitors (PIs) or non-nucleoside reverse transcriptase inhibitors (NNRTIS) are used as part of the regimen.

The rationale for therapy is to suppress viral replication below detectable limits in the plasma, thereby minimising the possibility of viral resistance. However, even partial viral suppression is usually accompanied by an improved clinical outcome.

\section{ADHERENCE}

Adherence to ART is vital for a successful outcome. The factors that impact on adherence include:

Affordability. Before initiating therapy, treaters should ascertain the affordability of a proposed regimen over a prolonged period of time. Anyone not being able to afford therapy should be referred to the state sector.

Motivation and commitment of caregiver/parent to the child's lifelong therapy. Adherence involves administering every dose of medication usually twice daily, every day of every year. Weekends away, schooling and other parental obligations need to be anticipated and planned for.

- Parental/caregiver understanding that poor adherence is the single most important factor leading to drug failure and resistance, and implies loss of future therapeutic options.

- Acceptance. Address any social issues as appropriate.

- Liquid formulations are problematic in that they are invariably more expensive than tablets/capsules, often have an unpleasant taste, and in some cases involve administration of large volumes of liquids.

- Additional issues which can enhance adherence include:

- As far as possible children should be taught to swallow pills/capsules. This can be done using appropriately sized sweets.

- Disclosure at home is also to be encouraged to enhance the treatment support in the home environment.

- The caregiver should identify one other person who can help with treatment (treatment buddy) as a back-up.

- Syringes for liquid formulations should receive special attention. Make sure that the caregiver draws up the correct volume and expels excess air.

\begin{tabular}{|c|c|}
\hline Category & Characteristics \\
\hline $\mathrm{N}$ & $\begin{array}{l}\text { No signs or symptoms related HIV infection or only } 1 \\
\text { condition listed in A }\end{array}$ \\
\hline $\begin{array}{l}\text { A } \\
\text { (mild) }\end{array}$ & $\begin{array}{l}\text { Two or more conditions listed below but none from } B \text { or } C \text { : } \\
\text { Lymphadenopathy ( } \geq 0.5 \mathrm{~cm} \text { at more than } 2 \text { sites; } \\
\text { bilateral = } 1 \text { site) } \\
\text { Hepatomegaly } \\
\text { Splenomegaly } \\
\text { Parotitis } \\
\text { Dermatitis } \\
\text { Recurrent or persistent upper respiratory tract } \\
\text { infections, sinusitis, or otitis media }\end{array}$ \\
\hline $\begin{array}{l}\text { B } \\
\text { (moderate) }\end{array}$ & $\begin{array}{l}\text { Symptomatic conditions other than from } A \text { or } C \text { and } \\
\text { attributed to HIV infection; including but not limited to: } \\
\text { Anaemia }(<8 \mathrm{~g} / \mathrm{l}) \text {, neutropenia }\left(<1 \times 10^{9} / \mathrm{l}\right) \text {, } \\
\text { thrombocytopenia }\left(<100 \times 10^{9} / \mathrm{l}\right)-\text { persisting } \geq 30 \\
\text { days } \\
\text { Bacterial meningitis, pneumonia or sepsis (single } \\
\text { episode) } \\
\text { Candidiasis, persisting }>2 \text { months in children }>6 \\
\text { months of age } \\
\text { Cardiomyopathy } \\
\text { Cytomegalovirus (CMV) infection, onset }<1 \text { month of } \\
\text { age } \\
\text { Diarrhoea - recurrent or chronic } \\
\text { Hepatitis } \\
\text { Herpes simplex virus (HSV) stomatitis }>2 \text { episodes } \\
\text { within a year } \\
\text { HSV bronchitis, pneumonitis or oesophagitis with onset } \\
<1 \text { year of age } \\
\text { Herpes zoster (shingles) } \geq 2 \text { episodes or } \\
>1 \text { dermatome } \\
\text { Leiomyosarcoma } \\
\text { Lymphoid interstitial pneumonitis (LIP) or pulmonary } \\
\text { lymphoid hyperplasia complex } \\
\text { Nephropathy } \\
\text { Nocardiosis } \\
\text { Persistent fever ( } 1 \text { month) } \\
\text { Toxoplasmosis, onset }<1 \text { month of age } \\
\text { Varicella, disseminated }\end{array}$ \\
\hline $\begin{array}{l}\text { C } \\
\text { Any of the } \\
\text { following: } \\
\text { (severe) }\end{array}$ & $\begin{array}{l}\text { Serious bacterial infections, multiple or recurrent (at } \\
\text { least } 2 \text { culture-confirmed episodes within a 3-year } \\
\text { period) of: } \\
\text { septicaemia, pneumonia, meningitis, bone or joint } \\
\text { infection, or abscess of an internal organ or body } \\
\text { cavity } \\
\text { Candidiasis (oesophageal or pulmonary) } \\
\text { Disseminated fungal infections (coccidioidomycosis, } \\
\text { histoplasmosis, cryptococcosis) } \\
\text { Cryptococcal meningitis } \\
\text { CMV disease with onset at age }>1 \text { month (at site other } \\
\text { than lymph nodes, spleen, liver) } \\
\text { Encephalopathy } \\
\text { HSV causing mucocutaneous ulcer persisting }>1 \\
\text { month, or bronchitis, oesophagitis, pneumonitis, } \\
\text { oesophagitis in a child }>1 \text { month } \\
\text { Kaposi's sarcoma } \\
\text { Lymphoma: primary in brain, Burkitt's, immunoblastic, } \\
\text { large cell, B cell or unknown } \\
\text { Mycobacterium tuberculosis (disseminated or extra- } \\
\text { pulmonary) } \\
\text { Mycobacterium avium complex or Mycobacterium } \\
\text { kansasii (disseminated) } \\
\text { Pneumocystis jiroveci pneumonia (PCP) } \\
\text { Progressive multifocal leukoencephalopathy } \\
\text { Cerebral toxoplasmosis with onset }>1 \text { month of age } \\
\text { Wasting syndrome in the absence of illness other than } \\
\text { HIV that could explain the following: persistent weight } \\
\text { loss > } 10 \% \text { of baseline, or downward crossing of at least } \\
2 \text { of the following percentiles on a weight-for-age chart } \\
\text { (95th, 50th, } 25 \text { th, } 5 \text { th) in a child } \geq 1 \text { year of age; or } \\
<5 \text { th centile weight for height on } 2 \text { consecutive } \\
\text { measurements } \geq 30 \text { days apart plus (1) chronic } \\
\text { diarrhoea ( } 22 \text { loose stools per day } \geq 30 \text { days); or ( } 2 \text { ) } \\
\text { documented fever } \geq 30 \text { days intermittent or constant }\end{array}$ \\
\hline \multicolumn{2}{|c|}{ Source: MMWR 1994; 43: rr1-12. } \\
\hline
\end{tabular}




\begin{tabular}{|c|c|c|c|c|c|c|}
\hline \multirow[b]{3}{*}{ Immunological category } & \multicolumn{6}{|c|}{ Age of child } \\
\hline & \multicolumn{2}{|c|}{$<12$ months } & \multicolumn{2}{|c|}{$1-5$ years } & \multicolumn{2}{|c|}{$6-12$ years } \\
\hline & $\overline{\mathrm{CD} 4+/ \mu \mathrm{I}}$ & $\mathrm{CD} 4+\%$ & $\overline{\mathrm{CD} 4+/ \mu \mathrm{I}}$ & $\mathrm{CD} 4+\%$ & $\overline{\mathrm{CD} 4+\mu \mathrm{l}}$ & $\mathrm{CD} 4+\%$ \\
\hline 1. No immunosuppression & $>1500$ & $\geq 25$ & $\geq 1000$ & $\geq 25$ & $\geq 500$ & $\geq 25$ \\
\hline 2. Moderate immunosuppression & $750-1499$ & $15-24$ & $500-999$ & $15-24$ & $200-499$ & $15-24$ \\
\hline 3. Severe immunosuppression & $<750$ & $<15$ & $<500$ & $<15$ & $<200$ & $<15$ \\
\hline
\end{tabular}

- Dosages of liquid formulations should be rounded up to a convenient volume for administering.

NOTE:

Emphasise good adherence at each visit. It is useful to compare ART with therapy for diabetes and hypertension, both requiring lifelong therapy and where poor adherence is associated with disease progression.

- The treater should be aware that the doses need adjustment at each visit as the child grows.

- It is useful to dispense the antiretroviral drugs oneself or else to have them delivered to one's rooms to keep track of those patients who do not collect their medications on time. This could alert you to a potential adherence problem.

\section{CLASSIFICATION OF HIV IN CHILDREN}

The Centers for Disease Control have utilised both clinical and immunological parameters for paediatric practice (Tables I and II).

\section{INDICATIONS FOR STARTING ART IN CHILDREN}

Indications for starting ART in children are set out in Table III.

Starting highly active antiretroviral therapy (HAART) is never an emergency. It may be beneficial to wait until adherence can be assured and the family has been adequately counselled and are ready for the rigours of ART.

\section{INITIATION OF THERAPY}

\section{FIRST 1 - 2 VISITS}

A full clinical examination should be performed, including accurate baseline weight, height, and head circumference measurement for children aged under 2 years. Blood samples should be taken for HIV viral load and CD4+ count.

Counselling and information. Topics to be covered include:

HIV prognosis

Treatment

adherence

Drug formulations

- Taste issues (including taste test where appropriate)

- Initiate prophylaxis as indicated.

Ensure that family/caregivers have contact details for treating staff in case of any questions/adverse events.

\section{NEXT VISIT}

If therapy is indicated and if the family is adequately counselled and able to maintain adherence, dispense drugs. Graphically illustrate the drugs and how and when to take them, preferably with actual drugs or samples. You may want to consider observing administration of the drugs. If the family are not ready yet, continue counselling and work on barriers to adherence.

\section{DAY 2}

A quick phone call to make sure that everything is in order is a good idea.

\section{1 - 2 WEEKS LATER}

A phone call to the caregiver/parent is recommended to discuss tolerance and adherence issues. The government rollout programme recommends a visit 2 weeks after starting treatment where adherence is discussed and medication technique is checked.

\section{ONE MONTH AFTER STARTING TREATMENT}

The clinician should conduct a general examination and draw blood to monitor drug toxicity.

\section{TABLE III. INDICATIONS FOR STARTING ART IN CHILDREN}

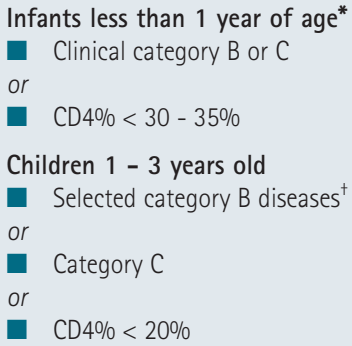

Children $4-12$ years old

- Selected category B diseases ${ }^{\dagger}$

or

- Category C

or

CD $4 \%<15-20 \%$

Adolescents $>13$ years

- Follow adult guidelines

*Infants under a year of age are most at risk for disease progression. Clinical and laboratory parameters are notoriously unreliable in predicting which infants will be rapid progressors. This explains the high CD4 cut-offs for initiating ART in this age group.

tSelected category B diseases: Persistent candida infection (> 2 months in children > 6 months old), cardiomyopathy, chronic diarrhoea, disseminated herpes simplex virus, leiomyosarcoma, lymphoid interstitial pneumonitis (LIP) or pulmonary lymphoid hyperplasia complex, nephropathy, disseminated varicella.

Note: Bronchiectasis is seen commonly but is not addressed in the classification. ART should begin prior to development of bronchiectasis. Pulmonary tuberculosis should be regarded as category $B$. 
Tolerance and adherence issues should be discussed. It may be useful to ask how many doses have been missed in the last 3 days, and how many in the last month.

\section{THREE MONTHS AFTER STARTING TREATMENT}

The clinician should conduct a general examination and draw blood to monitor drug toxicity. Check weight and alter doses accordingly.

Blood should be taken for HIV viral load and CD4+ count.

Adverse effects, tolerance and adherence issues should be discussed with the caregiver.

\section{THREE-MONTHLY THEREAFTER}

The clinician should conduct a general examination and draw blood to monitor drug toxicity, HIV viral load and CD4+ count. Check weight and alter doses accordingly. If the patient's results remain stable, clinical examinations and blood tests can be carried out 6-monthly, but children aged under 2 years need to be seen at least 3-monthly to adjust drug doses according to growth.

Discuss adverse effects, tolerance and adherence issues with caregiver at every visit.

\section{MONITORING: SPECIAL CONSIDERATIONS} FOR CHILDREN

\section{VIRAL LOAD}

Historically the percentage of children on triple therapy achieving and maintaining a plasma viral load of below 400 copies/ml was 25 - 75\%. With our currently available regimens and attention to adherence, children should be achieving viral load suppression equivalent to that possible in adults. Recent cohort data suggest that we can achieve undetectable viral loads in over $80 \%$ of treatment-naïve children.

Therapeutic options for children are limited. The decision to switch therapy because of suboptimal response must therefore be made thoughtfully, and balanced against the risk of accumulating additional resistance by maintaining a nonsuppressive regimen. Many clinicians switch ARVs when the CD4\% or count consistently drops or definite evidence of clinical failure has occurred.

Such evidence includes:

Growth failure

- Neurodevelopmental deterioration

Disease progression.

Although there is no consensus, a growing number of international experts advise aggressively achieving and maintaining viral suppression.

Note:

Viral suppression of < 10-fold (1 log) at 8 - 12 weeks after starting ART may be inadequate.

- In children who have responded with durable but not absolute viral suppression, a reproducible increase $>3$-fold $(0.5 \mathrm{log})$ in children $\geq 2$ years and 5 -fold $(0.7 \mathrm{log})$ in infants
$<2$ years may be an indication to change ARVs.

- A repeat test is recommended whenever a routine measurement yields an unexpected result. It is usually not worth doing routine plasma HIV RNA levels during an intercurrent event. Additional non-routine testing may be indicated if the clinical condition changes.

- Two measurements should be performed 1 month apart before instituting changes.

- Viral loads can be temporarily raised for up to a month after intercurrent infections or vaccinations.

- Patients should be sequentially tested using the same method and the same laboratory.

\section{CD4+ LYMPHOCYTE COUNTS AND CD4+ PERCENTAGES}

The CD4+ count should be measured whenever the viral load is determined, except when the viral load is repeated to verify an unexpected result. CD4+ lymphocyte counts are much higher in infancy than adulthood but the CD4+ percentage remains relatively more constant, although this is also higher in children $<2$ years. CD4+ percentages may be easier to work with, but CD4+ counts should also be used and knowledge of normal values for age is a prerequisite. A CD4+ percentage below 15\% should be viewed in the same light as a CD4+ count $<200 / \mu \mathrm{l}$ in adults (refer Table II). Lymphopenia and lymphocytosis may over- or understate CD4 percentages or counts.

CD4+ counts/percentages are useful for monitoring response to ARVs. CD4+ counts can be temporarily lowered due to intercurrent infections or vaccinations and can take up to a month to recover.

Although there is a strong association between $\mathrm{CD} 4+$ depletion and opportunistic diseases, Pneumocystis pneumonia may occur in the first year of life despite 'normal' counts for age.

All HIV-infected or exposed children under 1 year of age should receive co-trimoxazole prophylaxis from 6 weeks of age. If the child is HIV infected, this can be stopped at 1 year if the CD4+ percentage is $>20 \%$, or once there has been immune recovery to $>20 \%$ on ART. If the child is HIV negative, co-trimoxazole can be stopped at 6 months of age as long as the mother is not breastfeeding.

\section{HEIGHT AND WEIGHT}

The 'Road to Health' chart is a valuable tool for monitoring the well-being of children. Failure to maintain growth is suggestive of progressive HIV disease or superimposed infection such as tuberculosis.

\section{RECOMMENDED ARV REGIMENS}

\section{ANTIRETROVIRAL DRUGS (TABLES IV - VI)}

A 4-drug regimen may be more effective than the standard 3 drugs in young infants because of extremely high viral loads, 
TABLE IV. ANTIRETROVIRAL DRUGS

$\begin{array}{ll}\text { Category I } & \text { Stavudine }(\mathrm{d} 4 \mathrm{~T})^{*} \\ \text { NRTI - thymidine base } & \text { Zidovudine }(\mathrm{ZDV})^{*} \\ \text { Category II } & \text { Didanosine }(\mathrm{ddIl})^{*} \\ \text { NRTI - other } & {\text { Lamivudine }(\mathrm{STC})^{*+}}^{\text {Abacavir }(\mathrm{ABC})^{*}} \\ \text { NtRTI } & \text { Tenofovir (TDF) } \\ \text { Category III } & \text { Nevirapine (NVP) } \\ \text { NNRTI } & \text { Efavirenz (EFV) } \\ \text { Category IV } & \text { Ritonavir (RTV) } \\ \text { PI } & \text { Nelfinavir (NFV) } \\ & \text { Lopinavir/ritonavir (LPV/RTV) } \\ & \text { Saquinavir (SOV) soft gel } \\ & \text { Indinavir (IDV) }\end{array}$

*Available in paediatric formulations.

${ }^{+}$Require single mutation for development of resistance and therefore some experts only use them in regimens with a good chance of attaining undetectable viral loads.

${ }^{\ddagger}$ Not yet available in paediatric formulation. Paediatric dosage still uncertain Requires Section 21 authorisation from the Medicines Control Council.

${ }^{\S}$ Efavirenz (EFV) is only available in capsule form. There are no data for children under 3 years of age.

$\mathrm{NRTI}=$ nucleoside reverse transcriptase inhibitor; NtRTI = nucleotide reverse transcriptase inhibitor; NNRTI = non-nucleoside reverse transcriptase inhibitor;

$\mathrm{PI}=$ protease inhibitor.

\begin{tabular}{|l} 
TABLE V. PREFERRED ARVs \\
\hline PREFERRED NRTI BACKBONE \\
d4T + 3TC \\
ZDV + 3TC \\
ZDV + ddl \\
ABC + 3TC \\
ABC + ZDV \\
Avoid \\
D4T + ddl - if possible \\
Contraindicated \\
D4T + ZDV \\
ddl + ddC \\
d4T + ddC \\
PREFERRED NNRTIs \\
$<3$ years NVP \\
> 3 years EFV or NVP \\
There are no data on EFV dosing for children $<3$ years of age \\
PREFERRED PI \\
Lopinavir/ritonavir (LPV/rtv) (Kaletra $\left.{ }^{\circledR}\right)$
\end{tabular}

\section{TABLE VI. RECOMMENDED ARV REGIMENS*}

\section{PREFERRED REGIMENS}

2 NRTIs + EFV or NVP (1 each from categories I, II and III) (or 3TC + ABC + III) 2 NRTIs + 1 PI (1 each from categories I, II and IV (or 3TC + ABC + IV))

NOTE: Resistance to EFV and NVP develops rapidly if undetectable viral loads are not achieved. Some experts feel they should only be used when viral loads are $<150000$ copies/ml or where good adherence can be assured.

\section{ONLY IN SPECIAL CIRCUMSTANCES:}

$1 \mathrm{NRTI}+\mathrm{EFV}$ or NVP + $1 \mathrm{PI}$ (1 each from categories I or II, + III + IV)

NOTE: Although very potent, this regimen leaves few alternatives for future use and should only be considered in special circumstances (toxicity or salvage).

$\mathrm{ABC}+\mathrm{ZDV}+3 \mathrm{TC}$

NOTE: Adult data indicate that this regimen is not as potent as other triple regimens, so should be avoided.

* To be read in conjunction with Table IV.

but should only be contemplated if parental commitment is obtained. This regimen will have long-term financial impact, as costs will increase dramatically as the child grows. The
TABLE VII. NATIONAL DOH ART DRUG CHOICES FOR CHILDREN

\begin{tabular}{|lll|}
\hline $\begin{array}{l}6 \text { months up } \\
\text { to } 3 \text { years }^{*}\end{array}$ & $\begin{array}{l}\text { Over } 3 \text { years } \\
\text { and }>10 \mathrm{~kg}\end{array}$ \\
\hline 1st line & $\begin{array}{l}\text { Stavudine (d4T) } \\
\text { Lamivudine (3TC) } \\
\text { Kaletra }{ }^{\circledR}\end{array}$ & $\begin{array}{l}\text { Stavudine (d4T) } \\
\text { Lamivudine (3TC) } \\
\text { Efavirenz }\end{array}$ \\
& $\begin{array}{l}\text { Zidovudine (AZT) } \\
\text { Didanosine (ddl) } \\
\text { 2nd line }\end{array}$ & $\begin{array}{l}\text { Zidovudine (AZT) } \\
\text { Didanosine (ddl) } \\
\text { Kaletra }{ }^{\circledR}\end{array}$ \\
& \\
${ }^{*}$ Since there is now a pharmacokinetic study on Kaletra in infants $<6$ months of age, \\
these infants can now receive the same regimens as children from 6 months to 3 \\
years (see Table VIII for dosages). \\
${ }^{+}$Efavirenz if the child is over 3 years and nevirapine if $<3$ years.
\end{tabular}

efficacy of downscaling to a 3-drug regimen awaits further studies. Consult the SA HIV Clinicians Society for suitable regimens.

\section{Current National Department of Health recommendations}

Regimens currently recommended by the Department of Health are set out in Table VII. It is recommended that children in the private sector receive the same regimens as children in the state sector to facilitate moving to the state sector in the event of the patient no longer being covered by health insurance.

\section{DOSAGES OF ARVs IN CHILDREN AND SIDE-EFFECTS}

See Tables VIII and IX.

\section{DRUG INTERACTIONS OF NOTE}

There are multiple opportunities for serious drug interactions. Clinicians are advised to scrutinise package information and seek advice if uncertain.

- Rifampicin reduces levels of indinavir, nelfinavir, saquinavir (protease inhibitors) and nevirapine and should not be used with any of these drugs.

Efavirenz causes reduced levels of clarithromycin, but not azithromycin.

Ritonavir should not be given with numerous drugs.

Of the antiepileptic drugs, sodium valproate is the safest to use with ARVs.

Ritonavir inhibits CYP P450 3A4 in the gut. This prevents the breakdown of inhaled steroids, leading to systemic absorption with resultant Cushing's syndrome. Rather use a NNRTI-containing combination if the patient is on inhaled or nasal steroids.

The following drugs are metabolised by cytochrome P450 (CYP3A4), hence there is the possibility of multiple interactions:

Pls

Saquinavir

Ritonavir

- Nelfinavir

- Indinavir

- Lopinavir. 


\section{ADDITIONAL PRACTICAL POINTS}

\section{NUCLEOSIDE ANALOGUES}

Resistance to nucleoside analogues is slow to develop, with the exception of 3TC. Resistance to 3TC is selected within weeks when part of a non-suppressive regimen, but this is not generally a problem if there is good adherence to a 3-drug combination. 3TC resistance may, however, sensitise HIV to the antiviral activity of ZDV, d4T and TDF, but the durability of this effect is uncertain. Also, HIV with the characteristic mutation for $3 \mathrm{TC}$ resistance, $\mathrm{M} 184 \mathrm{~V}$, is less pathogenic.

All nucleoside analogues have been associated with lactic acidosis, a rare but potentially life-threatening complication of treatment. The pathogenesis is believed to involve druginduced mitochondrial damage.

\section{PRACTICAL DOSING ADVICE}

Although paediatric dosages are calculated using the child's weight or surface area, one must consider the practicalities of the dose. A dose of $1.75 \mathrm{ml}$, for example, is very difficult to measure accurately, so a more practical dose would be $1.8 \mathrm{ml}$ (generally round upwards). Certain ARV solutions, e.g. LPV/RTV (Kaletra ${ }^{\circledR}$ ) or RTV (Norvir), are highly concentrated, so dosages do need to be calculated to the nearest one-tenth of a millilitre (but it is not necessary to calculate to the nearest one-hundredth). Others, e.g. ZDV, 3TC, NVP (Viramune ${ }^{\circledR}$ ) or $A B C$ (Ziagen $\left.{ }^{\circledR}\right)$ solutions, can quite safely be rounded up to the nearest millilitre. When using stavudine capsules dissolved in water, dosages can be rounded up to the nearest $5 \mathrm{mg}$. Every effort should be made to switch to tablets or capsules as soon as possible.

\section{HAART AFTER FAILED MTCT PROPHYLAXIS}

1. When nevirapine was used as a single dose in MTCT prophylaxis. In the HIVNET 012 study, up to $45 \%$ of HIVinfected infants had resistance mutations against NNRTIs after 1 dose of NVP to the mother and the infant for prevention of mother-to-child transmission (MTCT). There are emerging data in adults and children suggesting reduced efficacy of future NNRTI-containing regimens. It is therefore advisable to avoid nevirapine and efavirenz as part of first-line therapy in this situation.

2. If AZT monotherapy was used in MTCT prophylaxis. Data support the use of AZT as part of combination therapy in infected infants. Resistance has, however, been described.

3. If AZT and 3TC were used as dual therapy for MTCT prophylaxis, avoid 3TC only if the mother had a prolonged course of treatment without adequate viral suppression. However, in the usual short courses used for MTCT $(<4$ weeks), it would be acceptable to use 3TC in the HIVinfected infant.

4. If the mother was on triple combination therapy, where possible avoid the drugs the mother was taking, especially if she had a detectable viral load. If unavoidable, it is advisable to get resistance testing done on the infant first and only use those drugs to which the virus is sensitive. If the mother had a undetectable viral load, it is probably acceptable to use the same agents in her HIVinfected baby.

\section{TB TREATMENT AND HAART IN CHILDREN}

As a result of the interaction between rifampicin and the Pls and NNRTIs, one needs to modify the tuberculosis treatment or the ART or both.

Other factors to take into consideration are overlapping toxicities of TB drugs and ARVs, and immune reconstitution inflammatory syndrome (IRIS).

\section{Options:}

- Ideally delay initiation of ART until after the course of TB treatment. (Allow 2 weeks for the effects of rifampicin on the liver to 'wash out')

If the CD4 count at the start of TB treatment indicates the need for ART, then delay the initiation of ART for 1 - 2 months of TB treatment. This reduces the likelihood of immune reconstitution disease and enables identification of the likely causative drugs if toxicities develop. Use standard TB treatment together with ARVs compatible with rifampicin, i.e. 2 NRTIs + either ritonavir or efavirenz (children > 3 years). The efavirenz dose should be increased by $30 \%$. In practical terms, just adding an additional $50 \mathrm{mg}$ capsule of EFV to the child's calculated dose is probably adequate (currently under investigation in a PK study in Cape Town).

- Use rifabutin instead of rifampicin (difficult to obtain and very expensive); ritonavir should not be used with rifabutin.

In adults, extra RTV can be added to LPV/RTV (Kaletra ${ }^{\circledR}$ ) to overcome the effects of the rifampicin. Unfortunately there is, as yet, no paediatric recommendation. This is currently under investigation in a pharmacokinetic study in Cape Town. Please discuss with an expert in this matter.

\section{SPECIFIC ISSUES FOR ADOLESCENTS}

Adult guidelines are appropriate for post-pubertal adolescents (Tanner stage V) (Tables X and XI).

- For adolescents in early puberty (Tanner stages I and II) use paediatric guidelines).

- For intermediate puberty, use paediatric guidelines but monitor closely for toxicity.

- Non-adherence is problematic and strategies should be introduced to promote adherence, including more frequent visits and intensive counselling.

Disclosure of the child's diagnosis is an important issue in ensuring adherence in adolescents. Disclosure is a process 


\begin{tabular}{|c|c|c|c|c|c|}
\hline Drug & Formulations & Dosage (per dose) & Frequency & Storage & Comments \\
\hline \multicolumn{6}{|c|}{ Nucleoside reverse transcriptase inhibitors (NRTIs) } \\
\hline $\begin{array}{l}\text { Zidovudine } \\
\text { (ZDV) } \\
\text { Retrovir }^{\circledR}\end{array}$ & $\begin{array}{l}\text { Susp: } 10 \mathrm{mg} / \mathrm{ml} \\
\text { Caps: } 100 \mathrm{mg} \text {, } \\
250 \mathrm{mg} \\
\text { Tabs } 300 \mathrm{mg}\end{array}$ & $\begin{array}{l}\text { Neonates: } \\
4 \mathrm{mg} / \mathrm{kg} / \text { dose until } \\
29 \text { days } \\
\text { Paediatric: } \\
180 \text { - } 240 \mathrm{mg} / \mathrm{m}^{2}\end{array}$ & 2 & Room temperature & \\
\hline $\begin{array}{l}\text { Didanosine } \\
(d d l) \\
\text { Videx }^{\circledR}\end{array}$ & $\begin{array}{l}\text { Susp: } 10 \text { mg/ml } \\
\text { Tabs: } 25 \text { mg, } 50 \text { mg, } \\
100 \text { mg, } 150 \text { mg } \\
\text { Enteric-coated } \\
\text { didanosine (EC) } \\
250 \text { mg, } 400 \text { mg }\end{array}$ & $\begin{array}{l}\text { Neonates: } \\
50 \mathrm{mg} / \mathrm{m}^{2} / \text { dose } \\
\text { Paediatric: } \\
90 \text { - } 120 \mathrm{mg} / \mathrm{m}^{2}\end{array}$ & $\begin{array}{c}2 \\
2 \\
\text { Can give total daily } \\
\text { dosage } x 1\end{array}$ & $\begin{array}{l}\text { Refrigerate } \\
\text { suspension }\end{array}$ & $\begin{array}{l}\text { Half h pre-meals or } \\
1 \mathrm{~h} \text { after meal } \\
\text { Use single daily dose } \\
\text { if necessary for } \\
\text { adherence. Needs to } \\
\text { be separated from } \\
\text { PI by } 1 \text { - } 2 \text { h } \\
\text { (depending on } \\
\text { which PI) } \\
\text { EC ddl still needs to } \\
\text { be taken on empty } \\
\text { stomach but can be } \\
\text { given together } \\
\text { with PI } \\
\text { EC ddl capsules can } \\
\text { be opened and } \\
\text { sprinkled on food }\end{array}$ \\
\hline $\begin{array}{l}\text { Stavudine } \\
(\mathrm{d} 4 \mathrm{~T}) \\
\text { Zerit }^{\circledR}\end{array}$ & $\begin{array}{l}\text { Susp: } 1 \mathrm{mg} / \mathrm{ml} \\
\text { Caps: } 20 \mathrm{mg}, 30 \mathrm{mg} \text {, } \\
40 \mathrm{mg}\end{array}$ & $\begin{array}{l}\text { Neonates < } 29 \text { days: } \\
0.5 \mathrm{mg} / \mathrm{kg} / \text { dose } \\
\text { Paediatric: } \\
1 \mathrm{mg} / \mathrm{kg} / \text { dose }\end{array}$ & $\begin{array}{l}2 \\
2\end{array}$ & $\begin{array}{l}\text { Refrigerate } \\
\text { suspension }\end{array}$ & $\begin{array}{l}\text { Capsules stable in } \\
\text { water suspension } \\
\text { for } 24 \text { hours at room } \\
\text { temperature }\end{array}$ \\
\hline $\begin{array}{l}\text { Abacavir } \\
\text { Ziagen }{ }^{\circledR}\end{array}$ & $\begin{array}{l}\text { Susp: } 20 \mathrm{mg} / \mathrm{ml} \\
\text { Tabs: } 300 \mathrm{mg}\end{array}$ & $\begin{array}{l}\text { All ages: } \\
8 \mathrm{mg} / \mathrm{kg} / \text { dose }\end{array}$ & 2 & Room temperature & $\begin{array}{l}\text { Watch for } \\
\text { hypersensitivity } \\
\text { reaction. Do not } \\
\text { rechallenge after } \\
\text { hypersensitivity } \\
\text { reaction }\end{array}$ \\
\hline $\begin{array}{l}\text { Lamivudine } \\
\left.\text { (3TC }{ }^{\circledR}\right)\end{array}$ & $\begin{array}{l}\text { Susp: } 10 \mathrm{mg} / \mathrm{ml} \\
\text { Tabs: } 150 \mathrm{mg}\end{array}$ & $\begin{array}{l}\text { Neonates: } 2 \mathrm{mg} / \mathrm{kg} \\
\text { Paediatric: } 4 \mathrm{mg} / \mathrm{kg}\end{array}$ & $\begin{array}{l}2 \\
2\end{array}$ & Room temperature & \\
\hline
\end{tabular}

Non-nucleoside reverse transcriptase inhibitors (NNRTIs)

\begin{tabular}{|c|c|c|c|c|c|}
\hline $\begin{array}{l}\text { Nevirapine } \\
\text { Viramune }^{\circledR}\end{array}$ & $\begin{array}{l}\text { Susp: } 10 \mathrm{mg} / \mathrm{ml} \\
\text { Tabs: } 200 \mathrm{mg}\end{array}$ & $\begin{array}{l}\text { Neonates: } 5 \mathrm{mg} / \mathrm{kg} / \\
\text { day od x } 14 \text { days then } \\
120 \mathrm{mg} / \mathrm{m}^{2} / \text { dose bd x } \\
14 \text { days then } \\
200 \mathrm{mg} / \mathrm{m}^{2} / \text { dose bd } \\
\text { Paediatric: } \\
120 \text { - } 200 \mathrm{mg} / \mathrm{m}^{2} \\
\text { Start at } 120 \mathrm{mg} / \mathrm{m}^{2} \\
\text { daily for } 14 \text { days and } \\
\text { increase to bd dosage } \\
\text { if no rash or severe } \\
\text { side-effects }\end{array}$ & 2 & Room temperature & $\begin{array}{l}\text { Skin rash usually } \\
\text { occurs in } 1 \text { st } 6 \\
\text { weeks; do not } \\
\text { increase dosage until } \\
\text { rash resolves } \\
\text { Watch for liver } \\
\text { toxicity } \\
\text { Try to maintain } \\
\text { dosage }>150 \mathrm{mg} / \mathrm{m}^{2} / \\
\text { dose bd }\end{array}$ \\
\hline $\begin{array}{l}\text { Efavirenz } \\
\text { Stocrin }{ }^{\circledR}\end{array}$ & $\begin{array}{l}\text { Caps: } 50 \text { and } 200 \text { mg } \\
\text { (Suspension available } \\
\text { from manufacturer) }\end{array}$ & $\begin{array}{l}10-<15 \mathrm{~kg}: 200 \mathrm{mg} \\
15-<20 \mathrm{~kg}: 250 \mathrm{mg} \\
20-<25 \mathrm{~kg}: 300 \mathrm{mg} \\
25-<32.5 \mathrm{~kg}: 350 \mathrm{mg} \\
32.5-<40 \mathrm{~kg}: 400 \mathrm{mg} \\
>40 \mathrm{~kg}: 600 \mathrm{mg}\end{array}$ & 1 & Room temperature & $\begin{array}{l}\text { No data }<3 \text { yrs and } \\
<10 \mathrm{~kg} \text {. Give at } \\
\text { night to avoid CNS } \\
\text { side-effects. Capsules } \\
\text { can be opened \& } \\
\text { given with food. } \\
\text { Anticipate CNS side- } \\
\text { effects (frequently } \\
\text { nightmares) - } \\
\text { potential source of } \\
\text { early poor adherence }\end{array}$ \\
\hline
\end{tabular}


TABLE VIII. DOSAGE AND FREQUENCY OF ARVs IN CHILDREN (CONTINUED)

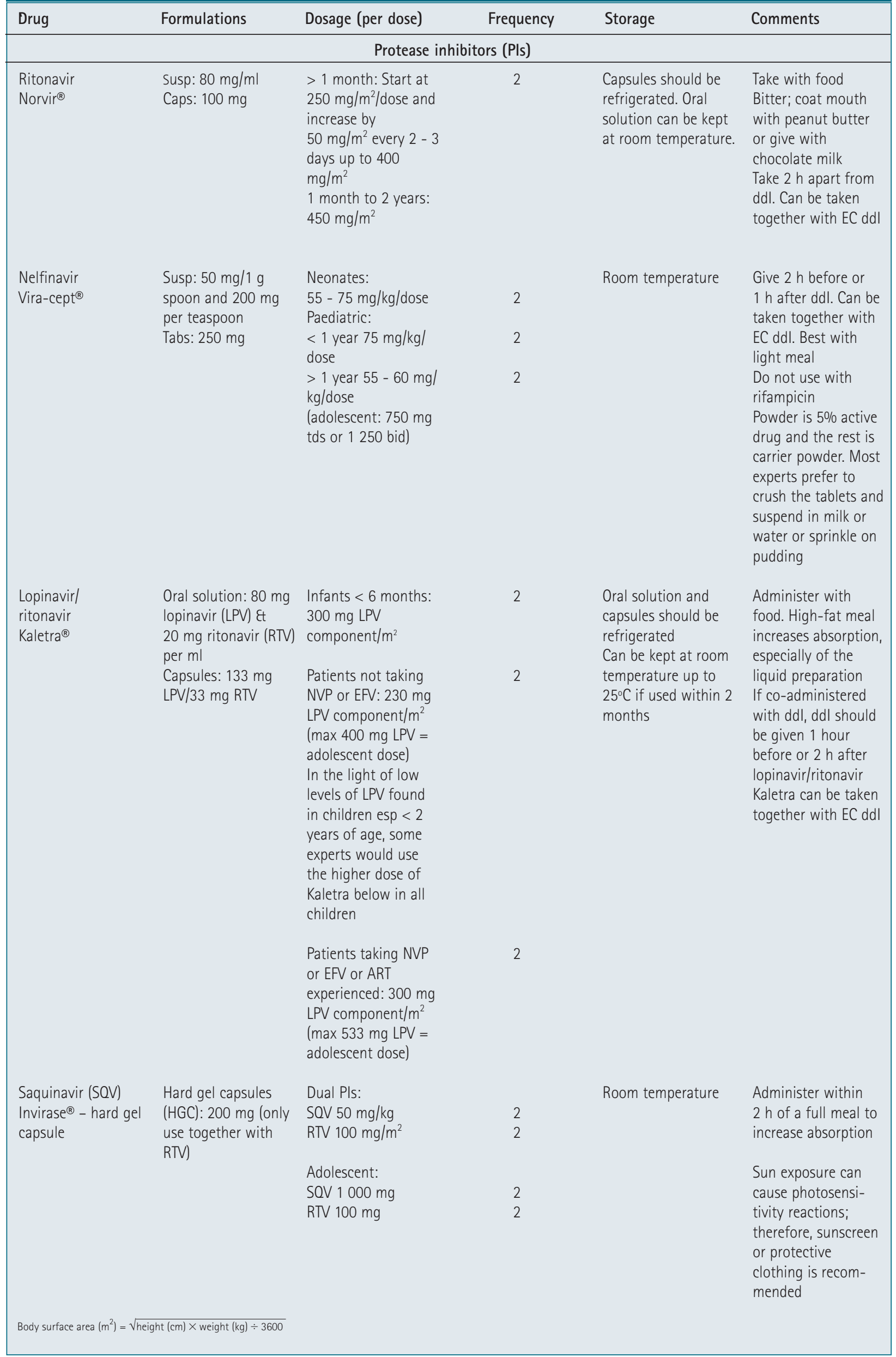




\begin{tabular}{|c|c|c|}
\hline Class & Drug & Side-effects \\
\hline \multirow[t]{8}{*}{ NRTI } & ZDV & Anaemia, granulocytopenia \\
\hline & (Retrovir ${ }^{\circledR}$ ) & Myopathy, lactic acidosis \\
\hline & ddl & $\begin{array}{l}\text { Common: abdominal pain, nausea and } \\
\text { vomiting }\end{array}$ \\
\hline & $\left(\right.$ Videx $\left.{ }^{\circledR}\right)$ & $\begin{array}{l}\text { Uncommon: pancreatitis, peripheral } \\
\text { neuropathy, lactic acidosis }\end{array}$ \\
\hline & $\begin{array}{l}\text { Stavudine } \\
\text { (Zerit }{ }^{\circledR} \text { ) }\end{array}$ & $\begin{array}{l}\text { Common: headache, rash, gastrointestinal } \\
\text { Uncommon: lipoatrophy, pancreatitis, } \\
\text { peripheral neuropathy, lactic acidosis }\end{array}$ \\
\hline & $\begin{array}{l}\text { Abacavir } \\
\left.\text { (Ziagen }{ }^{\circledR}\right)\end{array}$ & $\begin{array}{l}\text { Hypersensitivity reaction (with or without } \\
\text { rash) - fever, rash, fatigue, nausea, vomiting, } \\
\text { diarrhoea, pharyngitis, dyspnoea and cough, } \\
\text { elevated ALT, creatinine or CPK lymphopenia } \\
\text { Lactic acidosis }\end{array}$ \\
\hline & & $\begin{array}{l}\text { Common: headache, fatigue and abdominal } \\
\text { pain }\end{array}$ \\
\hline & $\left(3 \mathrm{TC}^{\circledR}\right)$ & Uncommon: lactic acidosis \\
\hline \multirow[t]{2}{*}{ NNRTI } & $\begin{array}{l}\text { Nevirapine } \\
\text { (Viramune }^{\circledR} \text { ) }\end{array}$ & $\begin{array}{l}\text { Skin rash, sedative effect and diarrhoea. Liver } \\
\text { toxicity }\end{array}$ \\
\hline & $\begin{array}{l}\text { Efavirenz } \\
\left.\text { (Stocrin }{ }^{\circledR}\right)\end{array}$ & $\begin{array}{l}\text { Skin rash } \\
\text { CNS - sleep disturbance, confusion, abnormal } \\
\text { thinking } \\
\text { Teratogenic in primates and humans }\end{array}$ \\
\hline \multirow[t]{3}{*}{$\mathrm{Pl}$} & $\begin{array}{l}\text { Ritonavir } \\
\text { (Norvir®) }\end{array}$ & $\begin{array}{l}\text { Nausea, vomiting, diarrhoea } \\
\text { Hypercholesterolaemia and } \\
\text { hypertriglyceridaemia, lipodystrophy }\end{array}$ \\
\hline & $\begin{array}{l}\text { Nelfinavir } \\
\left.\text { (Vira-cept }{ }^{\circledR}\right)\end{array}$ & $\begin{array}{l}\text { Diarrhoea } \\
\text { Can exacerbate chronic liver disease } \\
\text { Hypercholesterolaemia and } \\
\text { hypertriglyceridaemia }\end{array}$ \\
\hline & $\begin{array}{l}\text { Lopinavir/ } \\
\text { ritonavir } \\
\text { (Kaletra®) }\end{array}$ & $\begin{array}{l}\text { Nausea, vomiting, diarrhoea } \\
\text { Hypercholesterolaemia and } \\
\text { hypertriglyceridaemia, } \\
\text { lipodystrophy }\end{array}$ \\
\hline
\end{tabular}

that should begin from 7 years of age taking into account the child's cognitive ability.

\section{CHANGING THERAPY}

In case of toxicity or intolerance, a simple substitution can be made. Do not reduce dosage unless the reduced dose is still in the therapeutic range.

\section{TABLE X. TANNER STAGING FOR BOYS}

\begin{tabular}{|llll|}
\hline Stage & Pubic hair & Penis & Testes \\
\hline 1 & None & Pre-adolescent & Pre-adolescent \\
2 & $\begin{array}{l}\text { Scanty, long, } \\
\text { slightly pigmented }\end{array}$ & $\begin{array}{l}\text { Slight } \\
\text { enlargement }\end{array}$ & $\begin{array}{l}\text { Enlarged } \\
\text { scrotum, } \\
\text { pink texture } \\
\text { altered }\end{array}$ \\
3 & $\begin{array}{l}\text { Darker, starts } \\
\text { to curl, small } \\
\text { amount }\end{array}$ & Longer & Larger \\
4 & $\begin{array}{l}\text { Resembles adult, } \\
\text { less than adult }\end{array}$ & $\begin{array}{l}\text { Larger, glans } \\
\text { and breadth } \\
\text { increase size }\end{array}$ & Larger, scrotum \\
& dark \\
5 & $\begin{array}{l}\text { Adult distribution } \\
\text { spread to medial } \\
\text { surface of thighs }\end{array}$ & Adult & Adult \\
& & \\
\hline
\end{tabular}

TABLE XI. TANNER STAGING FOR GIRLS

\begin{tabular}{|c|c|c|}
\hline Stage & Pubic hair & Breasts \\
\hline 1 & Pre-adolescent & Pre-adolescent \\
\hline 2 & $\begin{array}{l}\text { Sparse, lightly } \\
\text { pigmented, straight, } \\
\text { medial border labia }\end{array}$ & $\begin{array}{l}\text { Breast and papilla elevated } \\
\text { as small mound; areola } \\
\text { diameter increased }\end{array}$ \\
\hline 3 & $\begin{array}{l}\text { Darker, beginning } \\
\text { to curl, increased } \\
\text { amount }\end{array}$ & $\begin{array}{l}\text { Breast and areola } \\
\text { enlarged, no contour } \\
\text { separation }\end{array}$ \\
\hline 4 & $\begin{array}{l}\text { Coarse, curly, } \\
\text { abundant but less } \\
\text { than adult }\end{array}$ & $\begin{array}{l}\text { Areola and papilla form } \\
\text { secondary mound }\end{array}$ \\
\hline 5 & $\begin{array}{l}\text { Adult feminine } \\
\text { triangle, spread to } \\
\text { medial surface of } \\
\text { thighs }\end{array}$ & $\begin{array}{l}\text { Mature; nipple projects, } \\
\text { areola part of general } \\
\text { breast contour }\end{array}$ \\
\hline
\end{tabular}

For failure of a regimen:

- First-line therapy. If the viral load is detectable even at a low rate, check and encourage adherence. Also check dosages or other 'technical problems' such as for vomiting or spitting out medications or not receiving medications on time.

If the viral load is persistently > 10000 copies/ml on 2 or 3 occasions despite good adherence and resolved technical problems, consider changing regimens. Be sure to resolve the adherence problems before changing therapy, otherwise the second regimen will also be doomed to failure.

- Second-line or subsequent regimens - consult an expert.

When failure is due to viral resistance, at least two drugs should be changed. Consider resistance testing (see below).

- Since future options are limited, whether to change and choice of new regimen should only be made by an experienced clinician.

- Consult the Southern African HIV Clinicians Society.

\section{RESISTANCE TESTING}

At present only genotypic resistance testing is available in South Africa. Genotyping is still an expensive option. Genotyping will only tell about resistance to drugs the patient is currently taking but not necessarily about resistance to previous ARVs the child may have been exposed to. For this reason, genotyping needs to be interpreted in conjunction with a detailed ARV drug history. The interpretation is complicated and should be done by an expert in the field. Generally genotyping is reserved for patients who have failed their second regimen because of the cost involved. However in paediatrics, because of the practice of continuing with a regimen that is failing virologically yet not immunologically or clinically, there may be a place for genotyping after failing a first regimen. There may also be a place for infants infected despite maternal HAART. Contact the Southern African HIV Clinicians Society for further information on when to perform and on interpreting genotyping. 


\section{SWITCHING FROM A PI-CONTAINING TO AN NNRTI-CONTAINING REGIMEN}

Numerous adult and one paediatric study have shown the feasibility of switching from a PI to an NNRTI where viral loads are $<50$ copies $/ \mathrm{ml}$ on a $\mathrm{Pl}$-containing triple regimen. This would help prevent some of the long-term adverse effects of the PIs. Where the mother and/or baby had been given a single dose of NVP to prevent MTCT, this practice should be avoided.

\section{INTERRUPTING THERAPY}

When stopping or interrupting a regimen containing an NNRTI, be aware that the long half-life of the NNRTI will cause subtherapeutic levels to persist for up to several weeks. Some experts favour either continuing the NRTIs for a week after stopping the NNRTI or switching to a PI to avoid developing resistance to the NNRTI.

\section{SELECTED ADVERSE EFFECTS OF ARVs IN CHILDREN}

ARVs are generally well tolerated in children. A few more serious adverse effects are mentioned here. For other adverse effects contact the Southern African HIV Clinicians Society.

\section{Lactic acidosis}

Lactic acidosis is a serious, life-threatening complication of NRTI therapy, especially ddl and d4T. Fortunately it is rare. Symptoms include nausea and vomiting, abdominal pain, tachypnoea and dyspnoea, weight loss and fatigue. It may also cause neurological symptoms including a Guillain Barré-like picture. There is no value in routine measurement of lactate levels. Clinicians should be aware of the symptoms and diagnose the condition timeously. Diagnosis is confirmed with a serum lactate level of $>5 \mathrm{mmol} / \mathrm{l}$, metabolic acidosis and a raised anion gap. Liver enzymes may also be increased.

In patients with a lactate level $>10 \mathrm{mmol} / /$ or $>5 \mathrm{mmol} / \mathrm{l}$ and metabolic acidosis, ART should be discontinued and supportive therapy instituted. Treatment (usually in an intensive care unit) consists of intravenous fluids and ensuring oxygenation of tissues with respiratory support, as needed. Some reports suggest that alkalinising the blood with bicarbonate might improve prognosis, but this remains controversial. Thiamine (vitamin $B_{1}$ ), riboflavin (vitamin $B_{2}$ ) and L-carnitine may be useful (there are no data to show efficacy).

Following an episode of lactic acidosis, it may take several months for lactate levels and liver enzymes to normalise. NRTIs should generally not be used again. Contact the Society for assistance in designing a new regimen after lactic acidosis.

\section{Haematological toxicity}

The two major agents implicated in causing haematological toxicity in HIV-infected patients are zidovudine and cotrimoxazole (usually only high-dose co-trimoxazole used in treating PCP, but occasionally prophylactic doses. It is reversible with folinic acid - not folic acid).
Patients on ZDV should have their full blood counts (FBCs) monitored monthly for the first 3 months and 3-monthly thereafter. The main bone marrow toxicities from ZDV are anaemia and neutropenia.

Anaemia may be due to HIV infection itself, AIDS-related conditions such as disseminated Mycobacterium avium complex (MAC), cytomegalovirus, or lymphoma, or it may be nutritional, e.g. iron or folate deficiency, or drug related. It is most commonly caused by ZDV but may be related to other ARVs. Management depends on the options available and the extent of the problem. It is reasonable to switch to a drug that causes fewer haematological side-effects, e.g. switch from ZDV to d4T. A haemoglobin level below 7 - $8 \mathrm{~g} / \mathrm{dl}$ warrants investigation and treatment. Nutritional deficiencies, especially of iron, should be addressed as well.

Neutropenia is quite common in children with HIV and in those on HAART. Unless severe, $<0.25 \times 10^{9} / \mathrm{l}$, it often resolves spontaneously (provided there are no associated signs such as persistent fever or localised infection) and a repeat FBC should simply be done a week later. If neutropenia is severe, $<0.25 \times 10^{9} /$, the offending agent should be replaced if feasible.

\section{Rashes}

Most rashes following ARVs are mild to moderate and resolve spontaneously with drug continuation. Most rashes are maculopapular or urticarial. The most severe rashes include Stevens-Johnson syndrome, toxic epidermal necrolysis, abacavir $(A B C)$ hypersensitivity reaction rash, and the drug rash with eosinophilia and systemic symptoms (DRESS) reported with NNRTIs.

The highest incidence of drug rashes occurs with the NNRTIs (more severe and more frequent with NVP). Rash usually occurs in the first 2 - 4 weeks of treatment. The rash is usually maculopapular and erythematous.

NVP is given daily for the first 2 weeks and only increased to twice daily once the rash has resolved. Mild to moderate rashes will often resolve spontaneously but need to be closely monitored. Oral antihistamines can be used. In children who develop severe rash, cutaneous bullae or target lesions, mucosal lesions or systemic symptoms, NVP should be permanently discontinued. If NVP is discontinued because of mild or moderate rash, restarting NVP after the rash has resolved may be considered with close monitoring.

Cross-reactivity among NNRTIs may occur. Therefore avoid EFV in children with a severe rash. However, in children with mild or moderate rash without mucosal involvement or systemic symptoms, substitution of efavirenz (EFV) may be done with caution.

Rashes may occur in children receiving EFV. These rashes are usually less severe than in those with NVP, and resolution of the rash during treatment continuation is common. However, 
if EFV-associated rash is severe, or is accompanied by mucosal or systemic symptoms, EFV should be permanently discontinued.

\section{Hypersensitivity syndrome}

Abacavir and nevirapine are most commonly implicated in hypersensitivity syndrome. ABC causes a systemic illness characterised by fever, rash, nausea, vomiting, diarrhoea, fatigue, myalgia and arthralgia. Respiratory symptoms, such as pharyngitis, cough, or dyspnoea may be present.

The skin rash occurs in about $70 \%$ of cases and is often maculopapular or urticarial. The $A B C$ hypersensitivity reaction occurs in $4-8 \%$ of patients, but it may be less common in black Africans. It usually occurs in the first 6 weeks after starting $A B C$. It is characterised by multisystem involvement and worsening of symptoms with each dose. $A B C$ hypersensitivity reaction is fully reversible on discontinuing abacavir, and is never fatal on first exposure to the drug. Patients must never be rechallenged with $A B C$ after a hypersensitivity reaction as deaths from hypotension have occurred.

A hypersensitivity reaction has been described for NVP. Systemic symptoms such as fever, myalgia, arthralgia, hepatitis and eosinophilia may occur. It usually occurs in the first 8 weeks of treatment. NVP should be permanently discontinued after a NVP hypersensitivity reaction and EFV should be avoided as well.

\section{Hepatotoxicity}

All three classes of ARV drugs currently in use in SA have been implicated. Liver dysfunction in HIV infection may be caused by HIV itself, co-infection with hepatitis B or C viruses or opportunistic infections, malignancies, drug interactions or drug-induced hepatotoxicity. NRTI-associated hepatotoxicity is primarily due to mitochondrial toxicity. NNRTIs are associated with asymptomatic elevations in liver enzymes and hypersensitivity reaction with hepatitis. NVP is associated with more hepatotoxicity than EFV. PI-associated elevations in liver enzymes can occur at any time during the course of therapy. Patients with chronic hepatitis B or C may experience an increase in liver enzymes after starting HAART as part of an immune reconstitution disease. Also, after discontinuing drugs such as 3TC or TDF (which are used to treat hepatitis B) there may be an increase in liver enzymes. Children do seem to get less hepatic dysfunction on HAART than adults.

Patients on NVP should have liver function tests (LFTs) done 2weekly for the first two months, then 3-monthly thereafter. LFTs should be monitored routinely 3 - 4-monthly in patients on other HAART regimens.

If transaminases are elevated $<10$ times the upper limit of normal (ULN) there is no need to interrupt HAART. Patients with clinical hepatitis or severe hepatotoxicity (> 10 $\times$ ULN) should have a work-up for other causes of hepatitis, e.g. hepatitis A, B or C, and HAART should be interrupted. Patients on NVP with clinical hepatitis should discontinue NVP and have their HAART regimen changed. Rechallenge with NVP or $A B C$ after acute hepatitis is not recommended. Patients with hepatitis B co-infection may need to continue with 3TC if their HAART regimen is changed to prevent a flare-up in their hepatitis B.

\section{Lipodystrophy}

Lipodystrophy typically involves accumulation of visceral fat in the abdomen (central obesity), dorsocervical area (buffalo hump) and breasts. There may also be loss of subcutaneous fat in the face, extremities and buttocks (lipoatrophy). The Pls have been implicated in causing the fat accumulation, whereas the NRTIs, especially stavudine, have been implicated in lipoatrophy. There are no data in children, but adult data suggest that switching from d4T or ZDV to ABC will partially reverse lipoatrophy but not the visceral fat accumulation. There are also limited data indicating that switching to a regimen containing a $\mathrm{PI}$ and an NNRTI only will also reverse lipoatrophy.

\section{Hyperlipidaemia}

The PIs (especially RTV and LPV/r) are the main ARVs implicated in causing hyperlipidaemia. However, both stavudine and efavirenz have also been implicated. While PI therapy in adults is associated with increased risk of cardiovascular disease, there is currently no evidence of an association between elevated cholesterol levels in children and an increased risk of premature death, as in adults. As a result, there has been no experience with lipid-lowering agents in children and there is no consensus in this regard. Cholesterols and triglycerides should be measured 6 - 12-monthly in children on Pls. A random cholesterol and triglyceride is probably adequate, but if these are raised a fasting level should be done. Referral to a dietician and encouraging exercise are the first interventions. If these are unsuccessful, consult the Southern African HIV Clinicians Society. Options available include observation, ARV agent switching (e.g. from a $\mathrm{PI}$ to an NNRTI) or lipid-lowering agents. Statins are metabolised by cytochrome P450 resulting in either toxicity or diminished effect when used with ritonavir, so these agents should be used with caution and only on the advice of an expert.

\section{RECOMMENDED READING}

1. Centers for Disease Control and Prevention. Guidelines for the use of antiretroviral agents in paediatric practice. MMWR 1998; 47: 1-43. Published and updated regularly on www.aidsinfo.nih.gov

2. Sharland M, Castelli G, Ramos JT, Blanche S, Gibb DM. On behalf of the PENTA Steering Committee. Penta Guidelines for the use of Antiretroviral Therapy in Paediatric HIV Infection www.ctu.mrc.ac.uk/PENTA/

3. World Health Organization guidelines www.who.int

4. National Department of Health guidelines www.doh.gov.za/ 
DISCLAIMER: Specific recommendations provided in this document are intended only as a guide to clinical therapy, based on expert consensus and best current evidence.

Recommended drugs and dosages are based on current available data and may differ from dosages recommended by manufacturers. Treatment decisions for patients should be made by their responsible clinicians with due consideration for individual circumstances. The most current version of this document should always be consulted.
GUIDELINES FOR ANTIRETROVIRAL THERAPY IN CHILDREN November 2005 VERSION

\section{Chairman}

Dr Leon Levin

Expert Panel Members

Prof Mark Cotton, Prof Glenda Gray, Dr Leon Levin,

Prof James Nuttal, Dr Helena Rabie, Dr Paul Roux and Dr Avye Violari

International Reviewers

Prof Stephane Blanche, Dr Elaine Abrams,

Dr Ann Melvin, Dr Andrew Pavia and

Dr Gareth Tudor-Williams

We acknowledge the assistance of Dr Lucille Blumberg in the section on $T B$ treatment and HAART in children.

\section{PAEDIATRIC ANTIRETROVIRAL THERAPY - HOW MANY GUIDELINES?}

With the development of the Society's two previous Paediatric Antiretroviral Therapy (ART) guidelines in 2000 and 2002 there were no other guidelines available in South Africa (SA), so our guidelines had to accommodate all children in SA. These guidelines were used both for children in the private sector and those in the State sector whose parents were funding their own therapy. However, since 2003 the Department of Health (DOH) has published excellent guidelines for treating children with ART in the state sector. These guidelines are more than sufficient for patients in the state sector who require ART, and are summarised in this journal on page 33. It is important to remember to consult the latest version of the $\mathrm{DOH}$ guidelines as previous versions are still in circulation, which are very cumbersome and impractical to use.

The Paediatric Sub-group's dilemma when designing their guidelines was to whom they should be targeted. Clearly there was no need to have extra guidelines for patients in the state sector. There are, however, no good guidelines for patients who have access to more resources and have more choice with regard to antiretroviral drugs and regimens and when to start ART. There are still quite a considerable number of patients on ART in the private sector. In addition, these patients may have been on therapy for a number of years now and some might already be on their second or third regimens. For this reason, a guideline was needed that took into account those choices that are available in the private sector. This guideline would need to introduce concepts such as genotyping for changing therapy, which may not be available to those patients in the state sector. These guidelines are in no way intended to undermine the $\mathrm{DOH}$ guidelines and are generally to be used only by those patients in the private sector who have access to other resources. It is my fervent hope that by the time the Society's Paediatric Antiretroviral Guidelines are next updated there will be no need for separate guidelines for the state and private sectors. We are making a concerted effort to work towards having only one guideline, but in the meantime people in the state sector are encouraged to use state sector guidelines and those in the private sector are encouraged to use these guidelines below.

The most important issue is not which guidelines we follow but that we treat these children. So many children out there need ART and are not receiving treatment. Even more devastating is the fact that a large number of children are dying from AIDS who should not be dying from what is clearly a controllable chronic disease. Children should be living with HIV and not dying from it.

I would like to thank the members of my committee for their contributions to these guidelines and for the effort and time they put into this endeavour. I would also like to thank our overseas reviewers, not only for critically reviewing these guidelines but for the contribution they are making to the advancement of paediatric ART in South Africa.

\section{LEON LEVIN}

Chairman, Southern African HIV Clinicians Society's Paediatric Sub-committee

November 2005 